\title{
Klasifikasi Mutu Pepaya Berdasarkan Ciri Tekstur GLCM Menggunakan Jaringan Saraf Tiruan
}

\author{
Feri Wibowo ${ }^{1 *}$, Agus Harjoko ${ }^{2}$ \\ ${ }^{1}$ Teknik Informatika \\ Universitas Muhammadiyah Purwokerto, Purwokerto \\ ${ }^{2}$ Departemen Ilmu Komputer dan Elektronika \\ Universitas Gadjah Mada, Yogyakarta \\ *feriwibowo@ump.ac.id
}

\begin{abstract}
Abstrak-Proses sortasi buah pepaya berdasarkan mutu merupakan salah satu proses yang sangat menentukan mutu buah pepaya yang akan dilepas ke konsumen. Proses identifikasi mutu dengan cara konvensional menggunakan visual mata manusia memiliki kelemahan di antaranya yaitu membutuhkan tenaga lebih banyak untuk memilah, tingkat persepsi manusia dalam hal pemutuan buah yang berbeda, tingkat konsistensi manusia dalam menilai mutu buah tidak menjamin karena manusia dapat mengalami kelelahan.

Penelitian ini bertujuan merancang dan menyusun program pengolahan citra digital dan jaringan saraf tiruan untuk klasifikasi pemutuan buah pepaya (Carica papaya L) Calina IPB-9 ke dalam tiga kelas mutu, yaitu kelas Super, A, dan B. Fitur tekstur yang diekstrak meliputi nilai energy, entropy, contras, bomogeneity, invers difference moment, variance, dan dissimilarity yang didapatkan berdasarkan GLCM (gray level cooccurrence matrices). Fitur-fitur tersebut dijadikan sebagai input pada algoritma pelatihan jaringan saraf tiruan backpropagation. Hasil pengujian pada proses pengenalan menunjukkan fitur energy, dan entropy dapat membedakan kelas mutu pepaya Calina IPB-9 dengan tingkat akurasi terbaik yaitu sebesar $86.11 \%$.
\end{abstract}

Kata Kunci: Klasifikasi, Mutu Pepaya, GLCM, Backpropagation

\section{Pendahuluan}

Papaya merupakan salah satu buah komoditas ekspor, Beberapa negara tujuan ekspor pepaya dari Indonesia adalah Hong Kong, Singapore, Malaysia, Kuwait, Qatar, Uni Emirat Arab, Bahrain, dan Thailand. Berdasarkan data dari pusat data dan sistem informasi pertanian Kementrian Pertanian Republik Indoneisa tahun 2014, volume ekspor pepaya tiga tahun terakhir dari tahun 2012, 2013, 2014 mengalami peningkatan dengan volume berturut-turut $25.328 \mathrm{Kg}, 25.836 \mathrm{Kg}$, dan $31.436 \mathrm{Kg}$. Berdasarkan data statistik Food \& Agriculture Organization (FAO) tahun 2000 sampai 2010 terkait dengan jumlah produksi pepaya, Indonesia merupakan salah satu negara penghasil pepaya dengan jumlah yang cukup besar di dunia, setelah Brazil, Meksiko, India, dan Nigeria [1].

Kebutuhan buah pepaya segar untuk tujuan ekspor membutuhkan penanganan mutu sehingga dapat bersaing dengan produsen buah pepaya dari negara lain. Salah satu permasalahan pascapanen adalah proses sortasi mutu pepaya. Selama ini identifikasi mutu dalam proses sortasi pepaya masih dilakukan secara konvensional menggunakan visual mata manusia yang memiliki keterbatasan. Proses identifikasi mutu dengan cara seperti ini memiliki beberapa kelemahan di antaranya yaitu membutuhkan tenaga lebih banyak untuk memilah, tingkat persepsi manusia dalam hal pemutuan buah yang berbeda, tingkat konsistensi manusia dalam menilai mutu buah tidak menjamin karena manusia dapat mengalami kelelahan [2].

Teknologi pengolahan citra digital dan metode jaringan saraf tiruan telah digunakan pada penelitian- penelitian sebelumnya terutama terkait dengan produkproduk hasil pertanian. Dalam penelitian [3] menentukan tingkat kematangan buah tomat (Lycopersicon esculentum Mill) menggunakan metode pengolahan citra dan jaringan saraf tiruan menggunakan parameter mean Red, mean Green, mean Blue, dan korelasi sebagai parameter masukan pada JST. Dalam [4] menerapkan teknologi pengolahan citra digital dan jaringan saraf tiruan untuk mengidentifikasi mutu fisik biji pala (Myristica fragrans houtt), pengujian fisik biji pala dilakukan secara non-destruktif meliputi warna, bentuk dan tekstur, kemudian keluaran adalah kelas mutu biji pala yang terdiri dari mutu ABC, mutu rimpel, dan mutu BWP. Penelitan [5] menggunakan jaringan saraf tiruan dan threshold rule untuk klasifikasi kematangan buah pepaya ke dalam tiga kategori yaitu pepaya belum matang, matang sedang, dan matang berdasarkan pada ratarata nilai RGB (red, green, blue). Penelitian [6] melakukan perancangan dan konstruksi mesin sortasi dengan sensor kamera CCD sebagai sensor citra dan unit pengolahannya untuk melakukan evaluasi pemutuan buah jeruk. Hasilnya adalah luas area buah jeruk dapat dijadikan acuan untuk pendugaan berat buah jeruk, luas area juga dapat digunakan untuk menentukan pemutuan buah jeruk sesuai kelasnya mulai dari kelas A sampai kelas E. Desain penelitian ini berbeda dengan penelitian sebelumnya di mana dalam penelitian ini menggunakan teknologi pengolahan citra digital dan metode jaringan saraf tiruan untuk klasifikasi kelas mutu buah pepaya (Carica papaya L) Calina IPB-9 ke dalam tiga kelas mutu, yaitu kelas Super, kelas A, dan kelas B. Klasifikasi kelas mutu didasarkan pada parameter citra yang didapatkan nilainya dari pengolahan citra digital. 


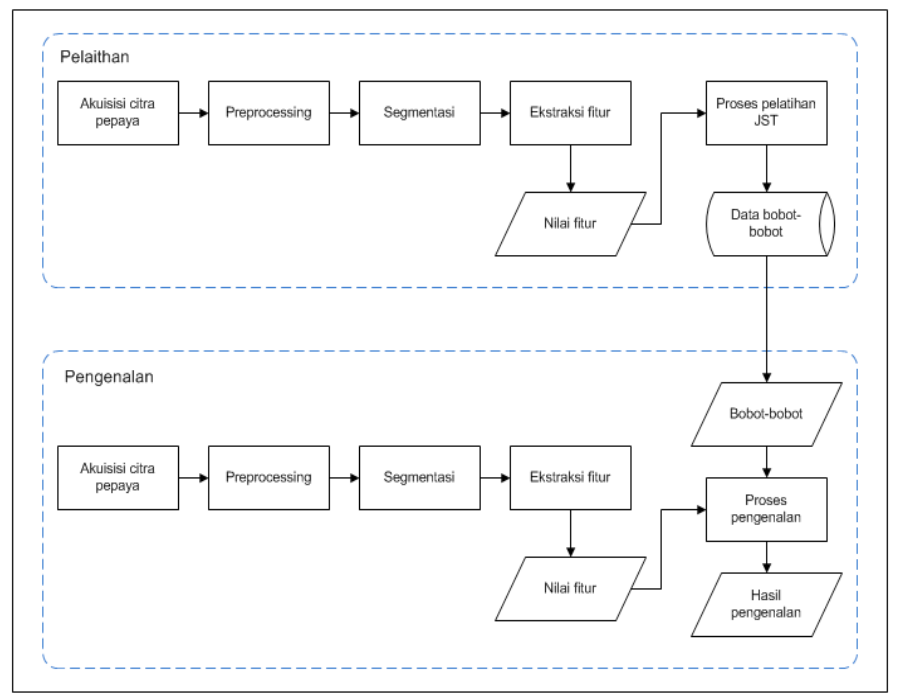

Gambar 1 Alur sistem klasisfikasi mutu pepaya

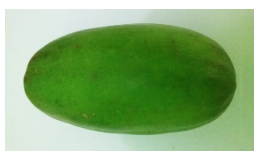

(a)

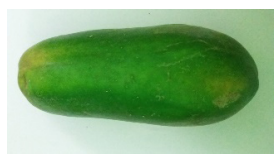

(b)

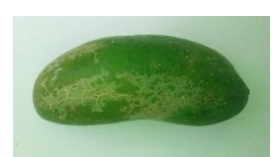

(c)

Gambar 2 Citra pepaya Calina IPB-9; (a) kelas super,

(b) kelas A, (c) kelas B

Nilai fitur yang didapatkan kemudian dijadikan sebagai input pada algoritma pembelajaran jaringan syaraf tiruan backpropagation.

\section{Metode}

Tahapan proses pada sistem yang dikembangkan, meliputi proses akuisisi citra, pengolahan citra untuk mendapatkan fitur citra, dan proses klasifikasi dengan jaringan syaraf Backpropagation yang terdiri dari pelatihan dan pengujian. Proses akuisisi dilakukan pada buah pepaya yang telah dipetik dan sudah dikelaskan berdasarkan kelas mutu yaitu kelas Super, A, dan B. Proses pengkelasan mutu ini dilakukan oleh petani pepaya yang sudah ahli dalam menilai mutu buah pepaya, selain itu pada saat proses pengkelasan, petani diberitahukan kriteria mutu buah pepaya berdasarkan standar kriteria yang dikeluarkan oleh Badan Standardisasi Nasional (BSN) Indonesia tahun 2009 nomor SNI 4230:2009, sebagai bahan pertimbangan pada saat proses pengkelasan. Citra pepaya hasil akuisisi akan diolah menggunakan teknologi pengolahan citra digital, yaitu melakukan ekstraksi fitur citra untuk memperoleh fitur tekstur. Fitur yang diperolah dari proses pengolahan citra digital dari data latih citra pepaya disimpan di database sebagai dataset yang digunakan sebagai data input pada tahap pelatihan backpropagation neural network untuk mendapatkan bobot-bobot, kemudian setelah diperoleh bobot-bobot dari pelatihan, bobot tersebut akan disimpan ke dalam database sebagai dataset pada tahap pengujian untuk mengklasifikasikan buah pepaya Calina IPB-9 berdasarkan mutu buah. Gambar 1 menunjukkan alur sistem klasifikasi mutu buah pepaya.

\section{A. Akuisisi Citra}

Proses akuisisi citra dilakukan pada buah pepaya Calina IPB-9 yang sudah dipetik dari pohonnya. Proses akuisisi dilakukan pada buah pepaya yang sudah dikelaskan berdasarkan kelas mutu yaitu kelas Super, A, dan B. Data citra yang diambil sejumlah 192 data citra dengan rincian 156 data latih yang terdiri dari 52 citra pepaya kelas super, 52 citra pepaya kelas A, dan 52 citra pepaya kelas B, dan data penguiian sebanyak 36 data citra pepaya. Sampel hasil akuisisi citra Pepaya Calina IPB-9 ditunjukkan pada Gambar 2.

\section{b. Preprocessing}

Proses prepocessing dilakukan dengan tujuan supaya meningkatkan kemungkinan keberhasilan pada tahap pengolahan lebih lanjut pada sebuah citra. Operasi yang dilakukan pada tahap prepocessing di antaranya adalah operasi resizing dan grayscaling. Resizing adalah proses mengubah resolusi atau mengubah ukuran horizontal dan vertikal citra. Operasi resizing yang dilakukan adalah mengubah ukuran citra dari ukuran semula yaitu $3264 \times 1836$ pixels menjadi $1024 \times 575$ pixels dengan tujuan supaya mempercepat pada saat proses pengolahan citra digital, karena semakin besar ukuran citra maka akan mempengaruhi waktu yang diperlukan pada saat proses pengolahan citra digital. Grayscaling adalah proses konversi citra dari citra warna RGB ke dalam bentuk citra berskala keabuan. Pada citra skala keabuan, warna dinyatakan dengan intensitas yang nilainya antara 0 sampai dengan 255, nilai 0 berarti hitam dan nilai 255 berarti putih. formula konversi ke citra ke skala keabuan atau grayscaling dapat menggunakan persamaan (1). 


\begin{tabular}{|l|l|l|l|l|}
\hline 2 & 1 & 2 & 0 & 1 \\
\hline 0 & 2 & 1 & 1 & 2 \\
\hline 0 & 1 & 2 & 2 & 0 \\
\hline 1 & 2 & 2 & 0 & 1 \\
\hline 2 & 0 & 1 & 0 & 1 \\
\hline
\end{tabular}

(a)

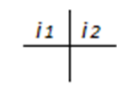

\begin{tabular}{|c|c|c|}
\hline & 1 & \\
\hline 0 & 1 & 3 \\
\hline 5 & 1 & 2 \\
\hline 1 & 4 & 2 \\
\hline
\end{tabular}

(b)

Gambar 3 (a) Citra berukuran 5x5 tiga intensitas (0, 1, 2); (b) GLCM jarak $(1,0)$

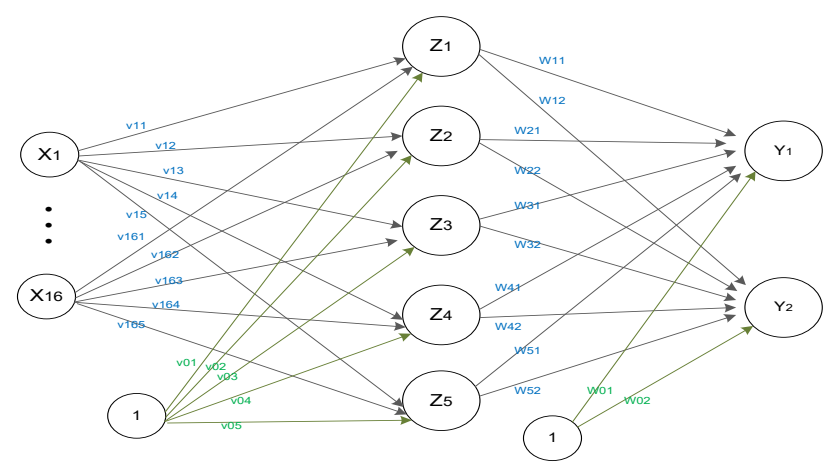

Gambar 4 Arsitektur jaringan saraf tiruan yang dibangun

$Y=0.2989 R+0.5870 G+0.1141 B$

$Y=0.2989 R+0.5870 G+0.1141 B$

$Y=0.2989 R+0.5870 G+0.1141 B$

\section{c. Segementasi}

Segmentasi citra merupakan proses yang ditujukan untuk mendapatkan objek-objek yang terkandung di dalam citra atau membagi citra ke dalam beberapa daerah dengan setiap objek atau daerah memiliki kemiripan atribut. Pada objek yang mengandung hanya satu objek, objek dibedakan dari latar belakangnya. Segmentasi juga biasa dilakukan sebagai langkah awal untuk proses klasifkasi sebuah objek. Teknik untuk melakukan segementasi citra didasarkan pada dua properti dasar nilai aras keabuan yaitu ketidaksinambungan dan kesamaan antarpiksel. Segmentasi citra didasarkan pada ketidaksinambungan nilai aras keabuan dapat dikatakan sebagai pemisahan citra didasarkan pada perubahan mendadak pada aras keabuan [7]. Segmentasi dengan memilih nilai ambang secara otomatis dapat dilakukan dengan metode Otsu. Metode Otsu merupakan metode yang dipublikasikan oleh Nobuyuki Otsu pada tahun 1979. Metode ini menentukan nilai ambang dengan cara membedakan dua kelompok, yaitu objek dan latar belakang, yang memiliki bagian saling bertumpukan, berdasarkan histogram.

\section{d. Ekstraksi Fitur}

Proses ekstraksi fitur menggunakan citra grayscale, citra biner, dan citra berwarna (RGB). Ekstraksi fitur dilakukan untuk mendapatkan fitur tekstur.

Tekstur dapat didefinisikan sebagai hubungan mutual antara nilai intensitas piksel-piksel yang bertetangga yang berulang di suatu area yang lebih luas daripada jarak hubungan tersebut. Metode yang digunakan untuk memperoleh fitur tekstur dapat dibedakan menjadi tiga golongan yaitu metode statistis, metode struktural, dan metode spektral. Menurut [7] metode statistis menggunakan perhitungan statistka untuk membentuk fitur. Contoh yang termasuk sebagai metode statistis yaitu GLCM (Gray Level Cooccurrence Matrices). Beberapa fitur tekstur yang akan dicari berdasarkan GLCM yaitu fitur energy, entropy, contras, homogeneity, invers difference moment (idm/local homogeneity), variance, dan dissimilarity. Matrik cooccurence yang akan dicari menggunakan jarak $(1,0)$, yang berarti satu piksel ke kanan dan nol piksel ke bawah, atau pasangan piksel yang harus dihitung adalah yang berjarak satu piksel dengan arah sudut 00 , seperti ditunjukkan pada Gambar 3.

Setelah didapatkan matrik cooccurence, selanjutnya mencari nilai fitur tekstur yang dapat dicari dengan persamaan (2) sampai persamaan (8).

$$
\begin{aligned}
& \text { energi }=\sum_{i=0}^{L-1} \sum_{j=0}^{L-1}[p(i, j)]^{2} \\
& \text { entropi }=-\sum_{i=0}^{L-1} \sum_{j=0}^{L-1} p(i, j) \log _{2}(p(i, j)) \\
& \text { kontras }=\sum_{i=0}^{L-1} \sum_{j=0}^{L-1}(i-j)^{2}(p(i, j)) \\
& \text { homogenitas }=\sum_{i=0}^{L-1} \sum_{j=0}^{L-1} \frac{P(i, j)}{1+|i-j|} \\
& \text { idm }=\sum_{i=0}^{L-1} \sum_{j=0}^{L-1} \frac{1}{1+(i-j)^{2}} p(i, j) \\
& \text { variance }=\sum_{i=0}^{L-1} \sum_{j=0}^{L-1}(i-\mu)^{2}(p(i, j)) \\
& \text { dissimilarity }=\sum_{i=0}^{L-1} \sum_{j=0}^{L-1}|i-j| p(i, j)
\end{aligned}
$$

\section{e. Rancangan Klasifikasi \\ Backpropagation Neural Network}

Algoritma pelatihan jaringan saraf backpropagation terdiri atas dua langkah, yaitu perambatan maju dan perambatan mundur, langkah perambatan maju dan perambatan mundur ini dilakukan pada jaringan untuk setiap pola yang diberikan selama jaringan mengalami pelatihan. Pada jaringan diberikan sepasang pola yang terdiri atas pola masukan dan pola keluaran yang diinginkan, ketika suatu pola diberikan kepada jaringan, bobot-bobot diubah untuk memperkecil perbedaan pola keluaran jaringan dan pola keluaran yang diinginkan [8].

Arsitektur jaringan backpropagation yang akan dibangun terdiri dari 3 lapisan yaitu lapisan masukan, lapisan tersembunyi, dan lapisan keluaran. Fitur-fitur yang diperoleh dari citra pepaya akan dijadikan sebagai input pada lapisan masukan pada jaringan saraf backpropagation. Fitur yang diperolah dari pengolahan citra berjumlah 7 fitur, maka unit input pada lapisan masukan akan berjumlah 7 unit. kemudian di bagian lapisan tesembunyi terdiri dari 5 unit. Di bagian lapisan keluaran ada 2 unit, karena ada 3 kelas mutu pepaya yang akan diklasifikasian maka ada 3 pasang pola keluaran, yaitu kelas Super $(1,1)$, kelas A $(1,0)$, dan kelas B $(0,1)$. Arsitktur jaringan backpropagation ditunjukkan pada Gambar 4.

Pengujian akan dilakukan dari kombinasi semua fitur, dan fitur yang merupakan fitur terbaik yang dihasilkan dari proses seleksi fitur. Akurasi sistem klasifikasi kelas mutu pepaya Calina IPB-9 dihitung dengan persamaan (11)

$\operatorname{akurasi}(\%)=\frac{j u m l a h \text { eitra pepaya dikenali sesuai kelas }}{\text { jumlah seluruh citra pepaya }} \times 100$ 
Tabel 1 Rata-rata hasil ekstraksi fitur

\begin{tabular}{lccc}
\hline \multicolumn{1}{c}{ Fitur } & SUPER & A & B \\
\hline Energy & 0.282673874 & 0.196039886 & 0.14863724 \\
Entropy & 0.169006472 & 0.201432957 & 0.226100682 \\
Contras & 0.127098174 & 0.13068448 & 0.154969185 \\
Homogeneity & 0.937202291 & 0.936034182 & 0.925138505 \\
Idm & 0.132501133 & 0.113911598 & 0.081385775 \\
Variance & 0.1540195223 & 0.1337657977 & 0.1242928107 \\
Dissimilarity & 0.125958447 & 0.128584198 & 0.150964249 \\
St Dev LBP & 2.647012889 & 2.369366267 & 2.184981344 \\
\hline
\end{tabular}

Tabel 2 Nilai maksimal dan minimal fitur tekstur GLCM

\begin{tabular}{|c|c|c|c|c|}
\hline & & SUPER & $\mathrm{A}$ & $\mathrm{B}$ \\
\hline \multirow{2}{*}{ Energi } & $\operatorname{Max}$ & 0.3538277 & 0.237287 & 0.177318 \\
\hline & Min & 0.225767 & 0.154514 & 0.117413 \\
\hline \multirow{2}{*}{ Entropi } & Max & 0.1865785 & 0.2246725 & 0.2466505 \\
\hline & Min & 0.1500783 & 0.182291 & 0.208605 \\
\hline \multirow{2}{*}{ Entropi Kontras } & Max & 0.161321 & 0.168363 & 0.23748 \\
\hline & Min & 0.099646 & 0.10121 & 0.102197 \\
\hline \multirow{2}{*}{ Homogenitas } & Max & 0.95109 & 0.950232 & 0.949133 \\
\hline & Min & 0.921414 & 0.921586 & 0.899289 \\
\hline \multirow{2}{*}{$\mathrm{Idm}$} & Max & 0.236734 & 0.2139 & 0.156796 \\
\hline & Min & 0.065694 & 0.073419 & 0.044753 \\
\hline \multirow{2}{*}{ Variance } & Max & 0.2284057 & 0.2326744 & 0.2115706 \\
\hline & Min & 0.065541 & 0.0454576 & 0.0449518 \\
\hline \multirow{2}{*}{ Dissimilarity } & Max & 0.158183 & 0.159429 & 0.208064 \\
\hline & Min & 0.098255 & 0.099947 & 0.10185 \\
\hline
\end{tabular}

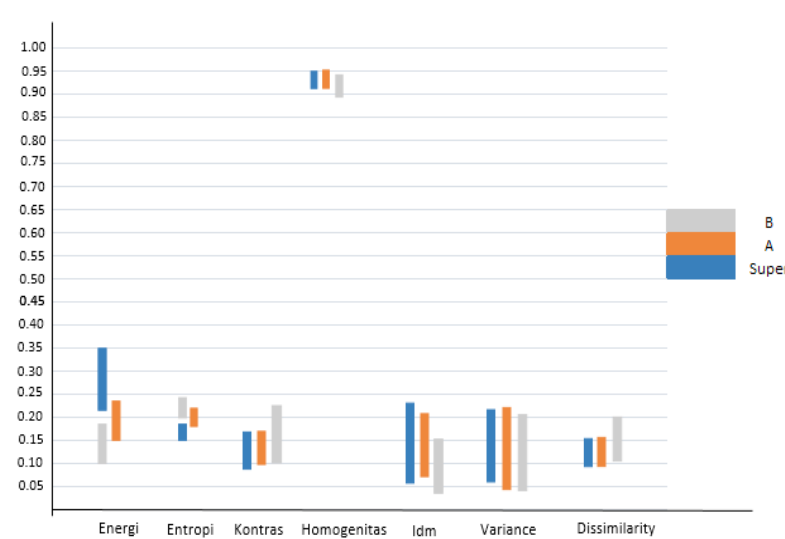

Gambar 5 Grafik fitur tekstur GLCM

Tabel 3 Hasil klasifikasi pada data latih

\begin{tabular}{llllll}
\hline No & Fitur yang Digunakan & Super A & B & Jumlah & $\begin{array}{c}\text { Dikenali } \\
(\%)\end{array}$ \\
\hline
\end{tabular}

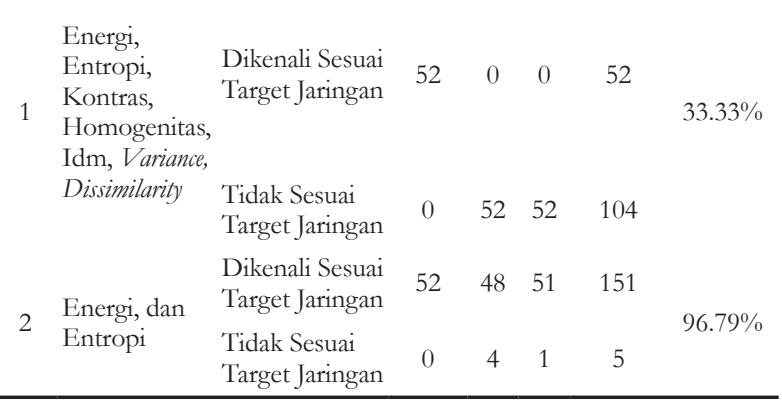

Tabel 4 Hasil pengujian klasifikasi dengan data uji

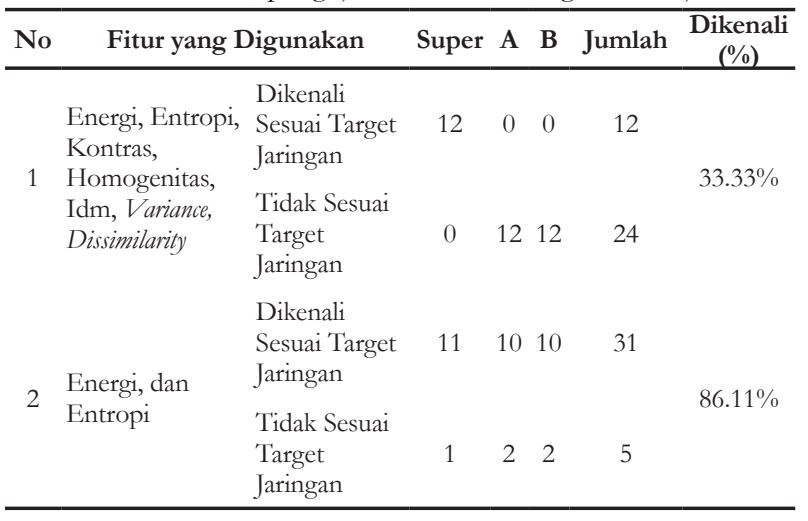

\section{Hasil dan Pembahasan}

Ekstraksi fitur meliputi fitur energy, entropy, contras, homogeneity, idm, variance, dissimilarity, dan standar deviasi dari LBP histogram. Tabel 1 menunjukkan nilai rata-rata fitur dari tiap kelas mutu citra pepaya.

Fitur-fitur yang telah didapatkan akan diseleksi terlebih dahulu sebelum digunakan sebagai input dalam proses klasifikasi. Pemilihan fitur dilakukan dengan cara melihat sebaran data fitur citra latih, setiap fitur diambil nilai maksimal dan minimal pada setiap kelas mutu yaitu kelas Super, A, dan B. Nilai maksimal dan minimal yang didapat akan dibuat grafik supaya terlihat perbedaan nilai fitur antar kelas mutu. Fitur yang baik akan terlihat setiap kelasnya tidak akan terjadi overlap atau setidaknya terjadi overlap sedikit saja pada tiap kelasnya dan sebaliknya fitur yang jelek akan terjadi banyak overlap pada tiap kelasnya. Tabel 2 menunjukkan data fitur terkait dengan nilai maksimal dan minimal fitur tiap kelas mutu.

Tabel nilai maksimal dan minimal fitur-fitur tekstur GLCM, terlihat bahwa fitur energy dan entropy mengalami overlap yang tidak terlalu banyak, atau terlihat fitur energy dan entropy mengalami overlap hanya pada kelas yang saling berdekatan, tidak terjadi overlap antar kelas Super ke kelas $B$ atau sebaliknya. Dari sekian fitur yang ada, maka yang paling memungkinan untuk digunakan sebagai input pada proses klasifikasi selanjutnya adalah fitur energy dan entropy. Gambar 5 menunjukkan grafik nilai maksimal dan minimal fitur GLCM.

Pengujian sistem klasifikasi mutu Pepaya Calina IPB9 menggunakan jaringan saraf backpropagation didasarkan pada data uji. Tahap pelatihan jaringan, menggunakan data latih sebanyak 156 data citra Pepaya Calina IPB-9. Parameter jaringan yaitu nilai learning rate sebesar 0,02, nilai maksimal epoch sebesar 250.000 dan nilai target error sebesar 0,001. Pengujian akan dilakukan beberapa kali mulai dari kombinasi semua fitur, fitur yang termasuk fitur bentuk, fitur yang termasuk fitur tekstur, fitur yang termasuk fitur warna, dan fitur yang merupakan fitur terbaik yang dihasilkan dari proses seleksi fitur. Hasil pengenalan klasifikasi pada data latih diperlihatan pada Tabel 3, dan hasil pengenalan klasifikasi terhadap data uji diperlihatkan pada Tabel 4.

Pada Tabel 3 diketahui jumlah citra latih yang dikenali sesuai kelas mutu dan jumlah citra yang dikenali tidak sesuai kelas mutu berdasarkan percobaan fitur-fitur yang ada. Pada proses seleksi fitur dihasilkan fitur yang paling baik adalah fitur energy dan entropy, kombinasi kedua fitur 
tersebut menghasilkan 151 data dikenali sesuai kelas mutu dan 5 data dikenali tidak sesuai dengan kelas mutu atau tingkat akurasi sebesar $96.79 \%$.

Pada Tabel 4 diketahui jumlah citra uji yang dikenali sesuai kelas mutu dan jumlah citra yang dikenali tidak sesuai kelas mutu berdasarkan percobaan kombinasi fiturfitur yang ada. Pada proses seleksi fitur dihasilkan fitur yang paling baik adalah fitur energy dan entropy, kombinasi kedua fitur tersebut menghasilkan 31 data dikenali sesuai kelas mutu dan 5 data dikenali tidak sesuai dengan kelas mutu atau tingkat akurasi sebesar $86.11 \%$.

\section{Kesimpulan}

Berdasarkan hasil penelitian klasifikasi mutu buah Pepaya Calina IPB-9 dengan teknologi pengolohan citra digital dan jaringan saraf tiruan diperoleh kesimpulan bahwa proses ekstraksi fitur didapatkan fitur energy, entropy, contras, homogeneity, idm, variance, dissimilarity. Hasil proses seleksi fitur didapatkan fitur yang terbaik yaitu fitur energy dan entropy karena kedua fitur tersebut mengalami overlap yang paling kecil. Proses pengujian klasifikasi pada data uji menggunakan fitur energy dan entropy menghasilkan nilai akurasi terbaik yaitu sebesar $86.11 \%$.

\section{Daftar Pustaka}

[1] Economic and Social Development Department, FAO., 2010, Medium-term prospects for agricultural commodities (Tropical Fruits), http://www.fao. org/docrep/006/y5143e/y5143e1a.htm

[2] Syaefullah, E., Purwadaria, H.K., \& Sutrisno, 2011, Pengolahan Citra Digital dan Jaringan Saraf Tiruan untuk Identifikasi Tingkat Ketuaan Pepaya, Prosiding Seminar Nasional Teknologi Inovatif Pascapanen Pertanian III, ISBN: 978-979-1116-32-9, Bogor.

[3] Hidayatullah, A., 2013, Identifikasi Tingkat Kematangan Buah Tomat (Lycopersicon esculentum Mill) Menggunakan Metode pengolahan citra digital dan jaringan saraf tiruan, Skripsi, Yogyakarta: UGM.

[4] Dinar, L., 2012. Identifikasi Mutu Fisik Biji Pala (Myristica Fragrans Houtt) Dengan Teknologi Pengolahan Citra Digital Dan Jaringan Sarat Tiruan. Tesis. Yogyakarta: UGM.

[5] Saad, H., \& Hussain, A. 2006, Classification for the Ripeness of Papayas Using Artificial Neural Network (ANN) and Threshold Rule. Student Conference on Research and Development -SCOReD, 1-4244-0527-0/06. Selangor.

[6] Ahmad, U., Tjahjohutomo, R., \& Mardison, 2008, Perancangan dan Konstruksi Mesin Sortasi dan Pemutuan Buah Jeruk dengan Sensor kamera CCD, Junal Keteknikan Pertanian (jTEP), ISSN 0216-3365, Bogor.

[7] Kadir, A. \& Susanto, A., 2013, Teori dan Aplikasi Pengolahan Citra, Penerbit Andi, Yogyakarta.

[8] Hermawan, A., 2006, Jaringan Saraf Tiruan Teori dan Aplikasi, Penerbit Andi, Yogyakarta. 